\title{
Impact of tannery effluent on Sorghum bicolor (L.) Moench
}

\author{
V. Sangeetha**, P.S. Sharavannan² \\ 'Department of Plant Science, Manonmaniam Sundaranar University, Triunelvelei-627012, Tamilnadu, India, '2Department \\ of Botany, M.R. Government Arts College, Mannargudi, Tamilnadu, India
}

Received: December 04, 2020 Revised: July 12, 2021

Accepted: July 23, 2021

Published: August 09, 2021

*Corresponding Author:

V. Sangeetha,

Email: akmsangeeth@gmail.

com

\section{ABSTRACT}

The present study is aimed to investigate the effect of tannery effluent on different varieties of Sorghum bicolor. The disparate concentrations of tannery effluent viz., 5, 25, 50, 75 and 100\% were tested for its impacts on six varieties of Sorghum bicolor (L.) Moench (TNAU CO 5, TNAU CO 30, CO (S) 28, BSR 1, K Tall and Paiyur 1). The experimentation was carried out in a completely randomized design (CRD) with five replications. The impact of tannery effluent on the germination percentage, shoot length $(\mathrm{cm})$, root length $(\mathrm{cm})$, seedling weight $(\mathrm{g})$, vigour index, tolerance index and phytotoxicity were recorded. The outcome revealed that the parameters escalated in $5 \%$ effluent concentration and declined after $25 \%$ concentration of tannery effluent.

KEYWORDS: Tannery effluent, Sorghum bicolor, CRD, phytotoxicity, vigour index

\section{INTRODUCTION}

Water contamination is a worldwide crisis and it is a dominant global cause of disease and consequent death. Environmental contagion was caused by the emission of mixture of elements from manufacturing progression which has now become a constant environmental threat. The rapid industrialization and urbanisation, abundance of chemicals including dyes, pigments and aromatic molecular structural compounds and assortment of industrial functions such as tannery, textiles, printing, pharmaceuticals, sugar industry, paper, plastic and cosmetics are leading causes of water pollution (Swathanthra \& Rao, 2014; Tadesse \& Guya, 2017). Tannery sewage are categorised as the prominent pollutants among all manufacturing dissipates. India is the $3^{\text {rd }}$ largest manufacturer of leather in the globe containing about 3000 tanneries with annual processing capacity of 0.7 million tonnes of animal skins. The tannery industry waste matter is exceedingly noxious to flora and fauna precisely by the occurrence of surplus quantity of dissolved solids, chlorides, sulphides, chromium with an extremely elevated BOD, COD and conductivity in the effluent (Buljan \& Kral, 2011). Chromium (trivalent, Cr III and hexavalent, Cr VI) present in effluent is one of the uttermost venomous pollutants (Amir et al., 2017).

S. bicolor (L.) Moench is cultivated through the rainy and postrainy seasons in Tamil Nadu. Sorghum are imperative feed for farm animals, especially in the dry months when other feed resources are in short supply. The sorghum grain produced during the post-rainy period (Rabi) is from local and enhanced land races of better quality (bold, white, and with a sweeter taste) and hence chosen for human utilization. In contrast, the sorghum produced in the rainy time (Kharif) is from hybrids, with deprived grain quality, and is not much favoured for human consumption. About 50 percentage of the Kharif produce goes into substitute utilization such as poultry feed, alcohol, and animal feed, while Rabi sorghum is fully used as foodstuff (Rao et al., 2010). The objective of present study is to find the effect of tannery industry effluents (diluted and raw) on the seed germination and other parameters of the Sorghum bicolor.

\section{MATERIALS AND METHODS}

\section{Collection and physico-chemical properties of tannery effluent}

The effluent tasters were collected in plastic containers from the exit of a Tannery Industry, Ranipet, Vellore District, Tamil Nadu, India. The collected raw tannery effluents were investigated for their physico-chemical properties as per the method of American Public Health Association (APHA, 1998).

\section{Germination and growth studies on Sorghum bicolor}

The tannery effluent was prepared into 5, 25, 50, 75 and $100 \%$ concentrations using tap water and used for all experiments. Six varieties of Sorghum bicolor (TNAU CO 5, TNAU CO 30, CO

Copyright: (C) The authors. This article is open access and licensed under the terms of the Creative Commons Attribution License (http://creativecommons.org/licenses/by/4.0/) which permits unrestricted, use, distribution and reproduction in any medium, or format for any purpose, even commercially provided the work is properly cited. Attribution — You must give appropriate credit, provide a link to the license, and indicate if changes were made. 
(S) 28, BSR 1, K Tall and Paiyur 1) were acquired from Tamil Nadu Agricultural University (TNAU), Coimbatore, Tamil Nadu, India. The number of seeds germinated in the whole lot behaviour was calculated on each and every day up to 7 days. The total germination fraction was calculated by using the following formula: Germination $\%=$ Total No. of germinated seeds/Total number of seed sown $\times 100$

The seedlings were randomly selected on the $7^{\text {th }}$ day from each treatment for studying the plantlet expansion. The augmentation of the six varieties of Sorghum seedlings was deliberated by using a centimeter scale and the values were tabulated. The sprouts were taken, air-dried and their fresh weight was taken. The same plantlets were kept in a hot air oven at $80^{\circ} \mathrm{C}$ for $24 \mathrm{~h}$. Then, the tasters were kept in desiccators and their dry weight was taken using electrical single pan balance. Vigour index of the sprouts were assessed by using the precepts initiated by Abdul-Baki and Anderson (1973). Tolerance index of the plantlet were totaled by exerting the prescription posited by Turner and Marshal (1972).

\section{Phytotoxicity}

The rate of phytotoxicity of tannery seepage was assessed by maneuvering the rules recommended by Chou et al. (1978). Phytotoxicity $\%=$ Radicle length of control- Radicle length of test/Radicle length of control $\times 100$.

\section{RESULTS DISCUSSION}

\section{Physico-chemical Assets of Tannery Effluent}

The physico-chemical features of tannery effluent with its tolerance limit standards for agricultural irrigation is given in Table 1 . The tannery effluent was gray in colour with acidic (pH 6) in nature contained elevated amount of total dissolved solids $(11218 \mathrm{mg} / \mathrm{L})$. The electrical conductivity of the effluent was $14380 \mathrm{mMhos} / \mathrm{cm}$ with lofty biological oxygen demand $(960 \mathrm{mg} / \mathrm{L})$ and chemical oxygen demand $(4800 \mathrm{mg} / \mathrm{L})$. In the aggregate, a substantial amount of calcium $(671 \mathrm{mg} / \mathrm{L})$, magnesium (381 mg/L), sodium (1981 mg/L), sulphate (2888 mg/L) and chromium (14.34 mg/L) were also present in tannery sewage. The tolerance confines of the wastewater for farming irrigation as prescribed by Tamil Nadu Pollution Control Board (TNPCB) were also specified in the same table for similarity. Most of the factors are found to be exceeding the tolerance limits. The acidic $\mathrm{pH}$, excessive hardness, total suspended solids, BOD, COD and towering amount of this indicates that the effluent is inappropriate for the continuation of aquatic organisms owing to the decline of dissolved oxygen content (Zereenet al., 2013).

\section{Germination and Growth Studies on Sorghum Bicolor}

The consequence of various concentrations of tannery waste matter on seed germination proportion of six varieties of Sorghumbicolor is tabulated in Table 2. The elevated seed
Table 1: Physico-chemical investigation of tannery effluent with its tolerance limits for farming irrigation

\begin{tabular}{|c|c|c|c|}
\hline S. No. & Parameters & Raw effluent & $\begin{array}{l}\text { Tolerance limits for } \\
\text { farming irrigation } \\
\text { approved by TNPCB }\end{array}$ \\
\hline 1. & Colour & Gray colour & Colourless \\
\hline 2. & Odour & $\begin{array}{l}\text { Disagreeable } \\
\text { smell }\end{array}$ & Odourless \\
\hline 3. & $\mathrm{pH}$ & 6 & $5.5-9.0$ \\
\hline 4. & $\begin{array}{l}\text { Electrical conductivity } \\
\text { (mMhos/cm) }\end{array}$ & 14380 & - \\
\hline 5. & Temperature $\left({ }^{\circ} \mathrm{C}\right)$ & 32 & 40 \\
\hline 6. & Chloride & 2718 & 20 \\
\hline 7. & Total hardness & 2850 & - \\
\hline 8. & Total dissolved solids & 11218 & 200 \\
\hline 9. & Biological oxygen demand & 960 & 30 \\
\hline 10. & Chemical oxygen demand & 4800 & 250 \\
\hline 11. & Calcium as $\mathrm{CaCO}_{3}$ & 671 & - \\
\hline 12. & Magnesium as Mg & 381 & - \\
\hline 13. & Sodium & 1981 & - \\
\hline 14. & Sulphate & 2888 & 20 \\
\hline 15. & Total chromium & 14.34 & - \\
\hline
\end{tabular}

All parameters except colour, odour, $\mathrm{pH}, \mathrm{EC}$ and temperature are expressed in mg/L.; TNPCB- Tamil Nadu Pollution Control Board

germination fraction $(99,100,99,98,99$ and 99\%) for the six varieties (TNAU CO 5, TNAU CO 30, CO (S) 28, BSR 1, K Tall and Paiyurl) were documented at $5 \%$ application of tannery sewage. The lowest seed germination \% values $(19,23,20,21$, 20 and 18\%) were enlisted for the six variation of Sorghum bicolor at untreated tannery effluent. The enhancement in germination percentage at lesser concentrations indicates the stimulation of physiologically motionless seeds of the lot by the behavior as suggested by Kumari et al., 2014. It may be due to the diminution in level of toxic metabolites by dilution and enhancedexploitation of nutrients present in the effluent. Similar trends were also noted in case of shoot length, root length, fresh and dry of weight of the seedlings, vigor and tolerance index (Table 2) The root which constantly remains in direct contact with effluent with elevated concentrations of the effluent could influence cell multiplication or the growth (Hussain et al.,2010). The being of most favourable level of nutrients in the $5 \%$ diluted tannery effluent might have increased the growth and weights of seedlings (Mythili $\&$ Fathima, 2018).

\section{Phytotoxicity}

The effect of various concentrations of tannery effluent on phytotoxicity values of six varieties of Sorghumseedlings are presented in Table 2. The highest phytotoxicity values (7.5, 5.6, 6.2, 6.6, 6.9 and 8.2) for the varieties (TNAU CO 5, TNAU CO 30, CO (S) 28, BSR 1, K Tall and Paiyurl) were recorded at 100\% concentration of tannery effluent. Sorghum seedling growth and maturity are essential processes of life and propagation of plant species. They constantly dependent on the external situation, showing of an assortment ofcontaminant in lower concentration (5\%) diluted tannery effluent at enhanced the growth and maturity (Sangeetha et al., 2012). 
Table 2: Effects of different concentrations of tannery effluent on Sorghum bicolor (L.) Moench. varieties

\begin{tabular}{|c|c|c|c|c|c|c|}
\hline \multirow{2}{*}{$\begin{array}{l}\text { Tannery } \\
\text { Effluent } \\
\text { Treatments }\end{array}$} & \multicolumn{6}{|c|}{ Name of the varieties } \\
\hline & TNAU CO 5 & TNAU C0 30 & $\mathrm{CO}(\mathrm{S}) 28$ & BSR 1 & K Tall & Paiyur 1 \\
\hline \multicolumn{7}{|c|}{ Germination Percentage } \\
\hline Control & $91 \pm 4.55$ & $90 \pm 4.50$ & $90 \pm 4.50$ & $91 \pm 4.55$ & $90 \pm 4.50$ & $88 \pm 4.4$ \\
\hline 5 & $99 \pm 4.95$ & $100 \pm 5.0$ & $99 \pm 4.95$ & $98 \pm 4.9$ & $99 \pm 4.95$ & $99 \pm 4.95$ \\
\hline 25 & $80 \pm 4.00$ & $82 \pm 4.1$ & $81 \pm 4.05$ & $84 \pm 4.2$ & $83 \pm 4.15$ & $82 \pm 4.1$ \\
\hline 50 & $71 \pm 3.55$ & $69 \pm 3.45$ & $70 \pm 3.5$ & $71 \pm 3.55$ & $69 \pm 3.45$ & $70 \pm 3.5$ \\
\hline 75 & $48 \pm 2.4$ & $49 \pm 2.45$ & $45 \pm 2.25$ & $44 \pm 2.2$ & $41 \pm 2.05$ & $40 \pm 2.0$ \\
\hline 100 & $19 \pm 0.95$ & $23 \pm 1.15$ & $20 \pm 1.0$ & $21 \pm 1.05$ & $20 \pm 1.0$ & $18 \pm 0.9$ \\
\hline \multicolumn{7}{|c|}{ Shoot length $(\mathrm{cm} / \mathrm{plant})$} \\
\hline Control & $4.2 \pm 0.21$ & $5.7 \pm 0.28$ & $4.0 \pm 0.2$ & $4.3 \pm 0.21$ & $4.1 \pm 0.20$ & $3.8 \pm 0.19$ \\
\hline 5 & $6.8 \pm 0.34$ & $7.9 \pm 0.39$ & $5.5 \pm 0.27$ & $5.7 \pm 0.28$ & $5.3 \pm 0.26$ & $4.3 \pm 0.21$ \\
\hline 25 & $3.8 \pm 0.19$ & $4.5 \pm 0.22$ & $3.2 \pm 0.16$ & $3.0 \pm 0.15$ & $3.1 \pm 0.15$ & $3.4 \pm 0.17$ \\
\hline 50 & $2.7 \pm 0.13$ & $3.3 \pm 0.16$ & $2.5 \pm 0.12$ & $2.1 \pm 0.10$ & $2.0 \pm 0.1$ & $2.0 \pm 0.1$ \\
\hline 75 & $1.9 \pm 0.09$ & $1.6 \pm 0.08$ & $1.3 \pm 0.06$ & $1.2 \pm 0.06$ & $1.2 \pm 0.06$ & $1.2 \pm 0.06$ \\
\hline 100 & $0.8 \pm 0.04$ & $1.4 \pm 0.07$ & $0.9 \pm 0.04$ & $0.8 \pm 0.04$ & $0.6 \pm 0.03$ & $0.6 \pm 0.03$ \\
\hline \multicolumn{7}{|c|}{ Root length (cm/plant) } \\
\hline Control & $2.5 \pm 0.12$ & $3.0 \pm 0.15$ & $1.9 \pm 0.09$ & $1.8 \pm 0.09$ & $2.0 \pm 0.1$ & $1.7 \pm 0.08$ \\
\hline 5 & $3.2 \pm 0.16$ & $3.7 \pm 0.18$ & $2.0 \pm 0.1$ & $2.1 \pm 0.10$ & $2.7 \pm 0.13$ & $2.4 \pm 0.12$ \\
\hline 25 & $1.9 \pm 0.09$ & $2.7 \pm 0.13$ & $1.6 \pm 0.08$ & $1.5 \pm 0.07$ & $1.4 \pm 0.07$ & $1.2 \pm 0.06$ \\
\hline 50 & $1.2 \pm 0.06$ & $1.6 \pm 0.08$ & $1.3 \pm 0.06$ & $1.1 \pm 0.05$ & $1.0 \pm 0.05$ & $1.0 \pm 0.05$ \\
\hline 75 & $1.0 \pm 0.05$ & $1.2 \pm 0.06$ & $1.0 \pm 0.05$ & $0.8 \pm 0.04$ & $1.0 \pm 0.05$ & $1.0 \pm 0.05$ \\
\hline 100 & $0.9 \pm 0.04$ & $1.2 \pm 0.06$ & $0.8 \pm 0.04$ & $0.6 \pm 0.03$ & $0.4 \pm 0.02$ & $0.3 \pm 0.01$ \\
\hline \multicolumn{7}{|c|}{ Fresh weight (g/seedling) } \\
\hline Control & $5.4 \pm 0.27$ & $7.1 \pm 0.35$ & $5.6 \pm 0.28$ & $6.8 \pm 0.34$ & $5.7 \pm 0.28$ & $5.0 \pm 0.25$ \\
\hline 5 & $6.9 \pm 0.34$ & $9.4 \pm 0.47$ & $7.1 \pm 0.35$ & $7.4 \pm 0.37$ & $7.1 \pm 0.35$ & $6.5 \pm 0.32$ \\
\hline 25 & $4.9 \pm 0.24$ & $6.8 \pm 0.34$ & $5.0 \pm 0.25$ & $5.3 \pm 0.26$ & $5.1 \pm 0.25$ & $4.5 \pm 0.22$ \\
\hline 50 & $3.5 \pm 0.17$ & $5.7 \pm 0.28$ & $3.9 \pm 0.19$ & $4.1 \pm 0.20$ & $3.7 \pm 0.18$ & $3.7 \pm 0.18$ \\
\hline 75 & $3.1 \pm 0.15$ & $4.6 \pm 0.23$ & $3.2 \pm 0.16$ & $3.5 \pm 0.17$ & $2.9 \pm 0.14$ & $2.6 \pm 0.13$ \\
\hline 100 & $2.0 \pm 0.1$ & $2.8 \pm 0.14$ & $2.1 \pm 0.10$ & $2.2 \pm 0.11$ & $2.0 \pm 0.1$ & $1.7 \pm 0.08$ \\
\hline \multicolumn{7}{|c|}{ Dry weight (g/seedling) } \\
\hline Control & $2.8 \pm 0.14$ & $3.5 \pm 0.17$ & $2.7 \pm 0.13$ & $3.0 \pm 0.15$ & $2.9 \pm 0.14$ & $2.6 \pm 0.13$ \\
\hline 5 & $3.2 \pm 0.11$ & $4.0 \pm 0.2$ & $3.4 \pm 0.17$ & $3.5 \pm 0.15$ & $3.5 \pm 0.17$ & $3.1 \pm 0.15$ \\
\hline 25 & $2.1 \pm 0.10$ & $2.9 \pm 0.14$ & $2.2 \pm 0.11$ & $2.6 \pm 0.13$ & $2.0 \pm 0.1$ & $1.8 \pm 0.09$ \\
\hline 50 & $1.0 \pm 0.05$ & $1.4 \pm 0.07$ & $1.1 \pm 0.05$ & $1.1 \pm 0.05$ & $0.9 \pm 0.04$ & $0.9 \pm 0.04$ \\
\hline 75 & $0.7 \pm 0.03$ & $1.0 \pm 0.05$ & $0.8 \pm 0.04$ & $0.7 \pm 0.03$ & $0.6 \pm 0.03$ & $0.6 \pm 0.03$ \\
\hline 100 & $0.3 \pm 0.01$ & $0.8 \pm 0.04$ & $0.4 \pm 0.02$ & $0.6 \pm 0.03$ & $0.5 \pm 0.02$ & $0.4 \pm 0.02$ \\
\hline \multicolumn{7}{|l|}{ Vigour index } \\
\hline Control & $1540 \pm 77$ & $1710 \pm 85.5$ & $1342 \pm 67.1$ & $1408 \pm 70.4$ & $1512 \pm 75.6$ & $1180 \pm 59$ \\
\hline 5 & $1861 \pm 93.0$ & $1979 \pm 98.5$ & $1504 \pm 75.2$ & $1720 \pm 86$ & $1698 \pm 84.9$ & $1499 \pm 74.9$ \\
\hline 25 & $1310 \pm 65.5$ & $1570 \pm 78.5$ & $1190 \pm 59.5$ & $1280 \pm 64$ & $1321 \pm 66.0$ & $1001 \pm 50.0$ \\
\hline 50 & $901 \pm 45.0$ & $1100 \pm 55$ & $980 \pm 49$ & $875 \pm 43.7$ & $912 \pm 45.6$ & $780 \pm 39$ \\
\hline 75 & $523 \pm 26.1$ & $690 \pm 34.5$ & $570 \pm 28.5$ & $482 \pm 24.1$ & $376 \pm 18.8$ & $355 \pm 17.7$ \\
\hline 100 & $220 \pm 11$ & $310 \pm 15.5$ & $289 \pm 14.4$ & $198 \pm 9.9$ & $186 \pm 9.3$ & $173 \pm 8.6$ \\
\hline \multicolumn{7}{|c|}{ Tolerance index } \\
\hline Control & - & - & - & - & - & - \\
\hline 5 & $3.5 \pm 0.17$ & $4.9 \pm 0.24$ & $3.8 \pm 0.19$ & $3.5 \pm 0.17$ & $4.0 \pm 0.2$ & $3.3 \pm 0.16$ \\
\hline 25 & $2.1 \pm 0.10$ & $3.7 \pm 0.18$ & $2.9 \pm 0.14$ & $2.5 \pm 0.02$ & $2.9 \pm 0.14$ & $2.2 \pm 0.11$ \\
\hline 50 & $0.8 \pm 0.04$ & $1.9 \pm 0.09$ & $1.2 \pm 0.06$ & $1.0 \pm 0.05$ & $1.0 \pm 0.05$ & $1.0 \pm 0.05$ \\
\hline 75 & $0.3 \pm 0.01$ & $1.0 \pm 0.05$ & $0.8 \pm 0.04$ & $0.5 \pm 0.02$ & $0.7 \pm 0.03$ & $0.5 \pm 0.02$ \\
\hline 100 & $0.1 \pm 0.005$ & $0.9 \pm 0.04$ & $0.7 \pm 0.03$ & $0.6 \pm 0.03$ & $0.5 \pm 0.02$ & $0.5 \pm 0.02$ \\
\hline \multicolumn{7}{|c|}{ Phytotoxicity } \\
\hline Control & - & - & - & - & - & - \\
\hline 5 & $0.6 \pm 0.03$ & $0.4 \pm 0.02$ & $0.5 \pm 0.02$ & $0.6 \pm 0.03$ & $0.6 \pm 0.03$ & $0.5 \pm 0.02$ \\
\hline 25 & $2.8 \pm 0.14$ & $1.8 \pm 0.09$ & $2.1 \pm 0.10$ & $2.2 \pm 0.11$ & $2.5 \pm 1.25$ & $2.0 \pm 0.1$ \\
\hline 50 & $4.9 \pm 0.24$ & $3.8 \pm 0.19$ & $4.0 \pm 0.2$ & $4.1 \pm 0.20$ & $4.4 \pm 0.22$ & $4.3 \pm 0.21$ \\
\hline 75 & $6.3 \pm 0.31$ & $4.2 \pm 0.21$ & $5.3 \pm 0.26$ & $5.8 \pm 0.29$ & $5.8 \pm 2.9$ & $6.9 \pm 0.34$ \\
\hline 100 & $7.5 \pm 0.37$ & $5.6 \pm 0.28$ & $6.2 \pm 0.31$ & $6.6 \pm 0.33$ & $6.9 \pm 0.34$ & $8.2 \pm 0.41$ \\
\hline
\end{tabular}

\pm Standard deviation

\section{CONCLUSION}

The outcomes of this experiment clearly demonstrate that germination was drastically shortened in elevated concentration of tannery effluent (above 5\%). The adverse effects may be in this process of soaring amount of BOD, COD, suspended solids and heavy metals jointly with assorted kind of dissolved chemicals. Irrigation of the soil with raw tannery effluents or tannery effluent polluted water resources destructively affect the plant germination and growth and also expand acidity of the soil. 


\section{REFERENCES}

Abdul-Baki., A. A., \& Anderson, J. O. (1973). Vigour determination insoybean application of dairy manure on germination andemergence of some selected crops. Journal of Environmental Quality, 3, 396-399.

Amir, A., Rahim, R. N. R. A., \& Abdul-Talib, S. A. (2017). Removal of chromium hexavalent using agriculture waste. International Journal of Environmental Science Development, 8(4), 260-263. https://doi. org/10.18178/ijesd.2017.8.4.959

APHA, (American Public Health Association). (1998). Standard methods for the examination of water and wastewater. American Public Health Association, American Water Works Association, Water Pollution Control Federation (18 $8^{\text {th }}$ Eds.), Washington, D.C. New York.

Buljan, J., \& Kral, I., (2011).Introduction to treatment of tannery effluents. United Nations Industrial Development Organization (UNIDO) Vienna.

Chou, C. H., Chiang, Y. C., \& Khan, C. I. (1978). Impact of water pollution oncrop growth in Taiwan. Botanical Bulletin of Academia Sinica, 19, 107-124.

Hussain, F., Malik, S. A., Athar, M., Bashir, N., Younis, U., Hassan, M. U., \& Mahmood, S. (2010). Effect of tannery effluents on seed germination and growth of two sunflower cultivars, African Journal of Biotechnology, 9(32), 5113-5120.

Kumari, V., Kumar, S., Haq, I., Yadav, A., Singh, V. K., Ali, Z., \& Raj, A. (2014). Effect of tannery effluent toxicity on seed germination $\alpha$-amylase activity and early seedling growth of mung bean (Vigna radiata) seeds.
International Journal of Latest Research in Science and Technology, 3(4), 165-170.

Mythili, M., \& Fathima, M. (2018). Effect of tannery effluent on seed germination and seedling growth in Crotalaria juncea Linn. International Journal of Development Research, 8, (1), 18475-18478.

Rao, P. P., Basavaraj, G., Bhagavatula, S., \& Ahmed, W. (2010). An analysis of availability and utilisation of sorghum grain in India. Journal of SAT Agricultural Research, 8.

Sangeetha, R., Kamalahasan, B., \& Karthi, N. (2012). Use of tannery effluent for irrigation: an evaluative study on the response of antioxidant defenses in maize (Zea mays). International Food Research Journal, 19(2), 607-610.

Swathanthra, P. A., \& Rao, V. V. (2014). Adsorption of chromium (VI) from aqueous solution using a solid waste (Bagasse). International Journal of Emerging Trends Engineering Development, 5(3), 330-336.

Tadesse, G. L., and Guya, T. K. (2017). Impacts of tannery effluent on environments and human health. Journal of Environment and Earth Science, 7(3), 88-97.

Turner., RG and Marshal., C. (1972) Accumulation of zinc by sub cellular root of Agros tistannis Sibth. in relation of zinc tolerance. New Phytologist, 71, 671-676. https://doi.org/10.1111/j.1469-8137.1972.tb01277.x

Zereen, A., Wahid, A., Khan, Z. U. D., \& Sardar, A. A. (2014). Effect of tannery wastewater on the growth and yield of sunflower (Helianthus annuus L.). Bangladesh Journal of Botany, 42(2), 279-285. https:// doi.org/10.3329/bjb.v42i2.18030 